NBER WORKING PAPER SERIES

\title{
STUDENT LOAN CHOICE OVERLOAD
}

\author{
Benjamin M. Marx \\ Lesley J. Turner \\ Working Paper 25905 \\ http://www.nber.org/papers/w25905
}

\author{
NATIONAL BUREAU OF ECONOMIC RESEARCH \\ 1050 Massachusetts Avenue \\ Cambridge, MA 02138 \\ May 2019
}

We are grateful to the Russell Sage Foundation for financial support (under Award\# 98-17-02) and to the anonymous community college for carrying out the experiment and providing the data used in this study. This RCT was registered in the American Economic Association Registry for randomized control trials under trial number AEARCTR-0000633. We thank Drew Anderson, Eric Bettinger, Mark Long, Richard Thaler, and participants at the NBER Economics of Education Fall 2016 Program Meeting and the 2019 annual conference of the Association for Education Finance and Policy for helpful comments. Yuci Chen provided excellent research assistance. The project was approved by the UIUC Institutional Review Board under protocol \#15366. The views expressed herein are those of the authors and do not necessarily reflect the views of the National Bureau of Economic Research.

At least one co-author has disclosed a financial relationship of potential relevance for this research. Further information is available online at http://www.nber.org/papers/w25905.ack

NBER working papers are circulated for discussion and comment purposes. They have not been peer-reviewed or been subject to the review by the NBER Board of Directors that accompanies official NBER publications.

(C) 2019 by Benjamin M. Marx and Lesley J. Turner. All rights reserved. Short sections of text, not to exceed two paragraphs, may be quoted without explicit permission provided that full credit, including $\odot$ notice, is given to the source. 
Student Loan Choice Overload

Benjamin M. Marx and Lesley J. Turner

NBER Working Paper No. 25905

May 2019

JEL No. D12,D14,D91,H31,I22

\begin{abstract}
What influences college student borrowing? In a field experiment with a large community college, we send emails about federal student loans to students who have received information about financial aid but have not made a borrowing decision. A treatment reminding students that they need not borrow the maximum amount of available loan aid does not affect borrowing. Treatments referencing amounts borrowed by recent graduates shift students from borrowing the maximum amount to not borrowing. Consistent with the hypothesis that students experience choice overload when observing multiple dollar amounts, the response is largest among lowperforming students and arises from inaction.
\end{abstract}

\author{
Benjamin M. Marx \\ Department of Economics \\ Urbana, IL 61801 \\ USA \\ benmarx@illinois.edu \\ Lesley J. Turner \\ Department of Economics \\ University of Maryland \\ 3115E Tydings Hall \\ College Park, MD 20742 \\ and NBER \\ turner@econ.umd.edu
}

University of Illinois at Urbana-Champaign

214 David Kinley Hall, 1407 W. Gregory

A randomized controlled trials registry entry is available at https://www.socialscienceregistry.org/trials/633 


\section{Introduction}

Outstanding student loan debt in the U.S. has grown steadily over the past decade, exceeding $\$ 1.46$ trillion by the end of 2018 (Federal Reserve Bank of New York 2019). While estimated returns to college completion suggest that borrowing to finance college is optimal for the average young adult (Avery and Turner 2012), the returns to educational investments are uncertain, and some students might take on debt without generating offsetting increases in human capital or post-college earnings.1 Concerns that students are making uninformed borrowing decisions have led to calls for increased counseling, information, and guidance $2^{2}$ Such efforts are predicated on the assumption that additional information about loan options, terms, and future payments can help improve borrowers' decisions and financial well-being, but existing research provides mixed evidence on whether students benefit from information about borrowing options, outstanding loan debt, and expected repayments.

To help fill this gap, we present evidence from a field experiment in which students at a large, anonymous community college (hereafter, LACC). Our experimental treatments are designed to test between two models that could explain the fact that most students either forgo federal student loans or choose an amount exactly equal to the nonbinding loan "offer" listed in their financial aid award letters, whether or not the offered amount is the maximum amount available (Marx and Turner 2019). First, students could be inattentive to the fact that they can choose a different loan amount. Accordingly, our first treatment provides a reminder that students need not borrow the offered amount. Second, students could view the offer as a recommendation of the optimal loan size, leading to anchoring or updating one's own belief towards this amount. To test this, two additional treatments reference the

\footnotetext{
${ }^{1}$ In recent years, however, over half of all borrowers had not paid down even $\$ 1$ of their debt two years after entering repayment, and 20 percent had defaulted on their loans within five years of repayment entry (Looney and Yannelis 2015).

${ }^{2}$ For example, the 2018 PROSPER Act would have allowed institutions to require students to complete additional counseling before borrowing through federal loan programs, while the 2019 Know Before You Owe Act would require institutions to inform student borrowers of their likely income and monthly student loan payments (based on program of study and estimated loan debt at graduation) and include a statement that the student can borrow less than the amount of loan aid displayed in their financial aid award letter.
} 
unconditional (\$800) or conditional (\$3000) mean annual amount borrowed by past LACC graduates. We then test whether the reference-point treatments cause students to shift towards the (lower) reference points.

Our results indicate that students understand they have a choice over their loan amount but are easily overwhelmed by this choice. The reminder of the option to borrow less than the offered amount had no effect on loan take-up or the amount borrowed, suggesting that students were already aware of this possibility. Neither reference-point treatment led students to borrow the referenced amount, suggesting that students did not view the behavior of recent graduates as providing a useful reference point. Most striking, we find that both referencepoint treatments reduced the probability that a student borrowed at all by 11 percent. The probability of borrowing the maximum available amount also falls by approximately 11 percent, suggesting that the reference-point treatments induce students who would have borrowed the maximum amount to instead borrow nothing.

We argue that students' response to receiving references to amounts borrowed by other students is most consistent with choice overload, the theory that individuals may become overwhelmed when presented with too many options (Iyengar and Lepper 2000). We are not aware of any studies that find choice overload in response to the presentation of options that were already available, but several results support this explanation. First, we test whether the reference-point treatments affected the likelihood that a student made an active decision to decline the loan offer. We show that the reduction in borrowing is not explained by an increase in the number of students actively declining their loan offer, but rather an increase in the likelihood of making no decision (and thus receiving the default loan of $\$ 0$ ). Second, we test for heterogeneous effects by student characteristics. Choice overload should be most common for students who are unfamiliar with or unsupported in making a borrowing decision, are prone to using heuristics (e.g., complying with nudges), or have lower cognitive ability. We find heterogeneity in treatment effects consistent with all of these predictions. Estimated effect sizes are relatively larger for students who are new to the college and are 
significantly larger for students who are classified as independent (nontraditional) students.$^{3}$ Effects are concentrated among students who have borrowed in the past, i.e., those who were more likely to have previously complied with the nudge provided by the (nonzero) amount listed in LACC's financial aid award letters. Finally, using baseline academic performance as a proxy for cognitive ability, we find that students whose baseline grade point average (GPA) is below the median for their level of credit accumulation are significantly more affected than their above-median-GPA counterparts.

Our paper contributes to a body of evidence that the design of federal student aid programs may hinder students' ability to take advantage of these resources. In particular, a growing literature suggests that student decisions are distorted by behavioral biases including debt aversion (Field 2009; Caetano et al. 2011), cognitive costs associated with complexity (Dynarski and Scott-Clayton 2006; Bettinger et al. 2012), issues of self-control (Cadena and Keys 2013), framing effects (Pallais 2015; J. Evans et al. 2018; Abraham et al. 2018), opt-in costs (Marx and Turner 2018), default bias (Cox et al. 2018), and salience (Marx and Turner 2019). Many first-year students either do not realize that they have taken out student loans or cannot recall the amount that they have borrowed (Akers and Chingos 2014), and only 20 percent of borrowers attending public institutions could answer two "loan literacy" questions

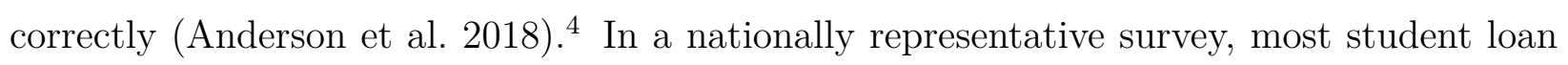
recipients stated that they did not calculate the size of their future monthly payments before deciding whether and how much to borrow (Lusardi et al. 2016).

Past interventions intended to help inform students' borrowing decisions have produced mixed results. Using a difference-in-differences design, Schmeiser et al. (2017) study a comprehensive intervention aimed at reducing borrowing among students carrying high loan balances at Montana State University and find only a 2 percent reduction in the amount

\footnotetext{
${ }^{3}$ An undergraduate student is classified as independent if she will be over the age of 24 by the end of the calendar year in which she is enrolled, is married, has dependent children, was in foster care or a ward of the court since age 13, is an emancipated minor, is a homeless unaccompanied youth, is currently serving on active duty in the military, or is a veteran.

${ }^{4}$ The questions tested for understanding of the consequences of defaulting on the loan and for knowledge of income-driven loan repayment plans.
} 
borrowed, with no effect on the probability of borrowing.5 In contrast, we find that simply sending students an email showing average borrowing of past graduates reduced the amount borrowed by 13 percent. Barr et al. (2017) show that text messages about loans and access to one-on-one counseling (provided via text message) reduced the amount borrowed and attainment among community college students who had applied for loan aid.6 Evidence from experiments in both the U.S. and the Netherlands suggest that student-loan-specific information alone does not significantly alter students' borrowing decisions, even when it increases students' understanding of loan terms and programs (Booij et al. 2012; Darolia and Harper 2018) 17 In contrast, changing the amount of loan aid listed in the financial aid award letter, without changing the cost to the college or the choices available to the student, significantly affects borrowing and attainment (Marx and Turner 2019).

Our findings also contribute to the literature on choice overload. In theoretical models, choice overload can arise from costs of searching for or evaluating options (Kuksov and VillasBoas 2010) or if individuals expect they may regret their choices (Sarver 2008, Buturak and Evren 2017). Increasing the number of available options has been found to increase the likelihood that agents make inefficient or dominated choices over retirement plans and savings (Benartzi and Thaler 2001; Iyengar et al. 2004; Iyengar and Kamenica 2010) and health insurance plans (Heiss et al.|2010; Abaluck and Gruber 2011; Zhou and Zhang 2012) 8 Our reference-point treatments do not introduce new options so much as increase the salience of alternatives, but our finding that they increase the likelihood of inaction is consistent with

\footnotetext{
${ }^{5}$ Starting in fall 2012, Montana State University sent letters to students with high outstanding debt that included an incentivized invitation to participate in a one-on-one counseling session with a certified financial counselor.

${ }^{6}$ Treatment status included a variety of interventions, including the ability to ask for assistance from financial aid staff and text messages with information about loan terms (e.g., lifetime limits, future payments), encouragement to complete required financial aid forms, and, similar to our experiment, reminders of the option to borrow less than the offered amount of loan aid and references to smaller loan amounts. Our experiment allows us to isolate the effects of each of the reminder and reference messages.

${ }^{7}$ An exception is Stoddard and Urban (forthcoming), who find that high school requirements that students complete financial education to graduate increase federal student aid applications and shift students from credit card debt in favor of federal student loans.

${ }^{8}$ Evidence from lab experiments involving choice over hypothetical health insurance plans is also consistent with choice overload (Schram and Sonnemans 2011; Johnson et al. 2013 ; Kairies-Schwarz et al. 2014. Bhargava et al. 2017).
} 
Shafir et al. (1993), who find that subjects in a lab experiment are more likely to choose to wait for more information when given two purchase options than when given a single option. Meta-analyses by Scheibehenne et al. (2010) and Chernev et al. (2015) find heterogeneity in the effect of additional options, with factors that appear to contribute to choice overload including choice set complexity and preference uncertainty. Both factors likely characterize students' choices of a specific dollar amount of loan aid needed for expenses to be incurred over an academic year.

The remainder of this paper proceeds as follows. In Section 2 , we describe the student loan program and our experimental site. Section 3 details the design of our experiment, while Section 4 describes our empirical framework. We present results in Section 5, including the main effects of the emails on borrowing outcomes, heterogeneity in these effects, and estimates of effects on attainment. Section 6 concludes.

\section{Student Financial Aid and LACC}

Low-income college students in the United States are eligible for federal grants and loans. In order to access federal aid, prospective students must fill out the free application for federal student aid (FAFSA) by providing information on their family income, assets, siblings, and other family members' college attendance. Older students, those with dependents, and those who are married are classified as "independent" and need only include their own income and assets in the FAFSA, while "dependent" students' EFCs take into account the resources of both students and their parents. These inputs are fed through a complicated, nonlinear formula to determine a student's expected family contribution (EFC), the federal government's measure of ability to pay. Eligibility for federal need-based grants, subsidized

loans, and campus-based aid generally depend on EFC, either directly (as in the case of Pell Grant aid) or when combined with additional information (as in the case of work-study funding). 


\subsection{Federal student loans}

All students who are enrolled at least part-time and have completed a FAFSA are eligible to borrow through federal loan programs. The primary source of federal loan aid for undergraduate students is the Direct Loan Program.9 The terms of federal loan aid depend on a student's course load, dependency status, class standing, and unmet need. While students must attempt at least 6 credits to be eligible to borrow, above this threshold, the terms of borrowing do not explicitly depend on a student's course load. A student's unmet need, equal to her total cost of attendance (tuition, fees, and a cost of living allowance) minus her EFC and total grant aid from all sources, determines her eligibility for subsidized loans, which do not accrue interest while in school. Students classified as freshmen are eligible for subsidized loans equal to the lesser of remaining need and $\$ 350010$ Community college students who are classified as sophomores are eligible for an additional $\$ 1000$ in subsidized loans ${ }^{11}$ Dependent undergraduate students face a lifetime eligibility limit of $\$ 31,000$ in federal loans, while the limit for independent undergraduate students is $\$ 57,500$.

Although the federal rules described in the previous paragraph dictate the amounts of subsidized and unsubsidized loans for which a college student is eligible, colleges can decide how much loan aid to offer in financial aid award letters. The Department of Education and college financial aid administrators call this process packaging. In all cases, not borrowing is the default: students who take no further action do not receive loans, regardless of the

\footnotetext{
${ }^{9}$ Student loan interest rates are pegged to the 10-year Treasury note interest rate plus 2.05 percent and are updated on an annual basis. Students in our study who had their loans disbursed before July 1 , 2016 faced an interest rate of 4.29 percent, while those loans disbursed between July 1, 2016 and June 30,2017 had an interest rate of 3.76 percent.

${ }^{10}$ Subsidized loan eligibility is also reduced when a student's remaining lifetime eligibility for subsidized loans $(\$ 23,000)$ is less than these amounts.

${ }^{11}$ Students enrolled in four-year institutions who are sophomores or juniors are classified as "upper-level" and are eligible for an additional $\$ 2000$ in subsidized loans. Regardless of credit accumulation, community college students cannot be classified as upper-level. At most institutions, dependent students can borrow an additional $\$ 2000$ in unsubsidized loans, and independent students can borrow an additional $\$ 4000$. At these institutions, students who do not qualify for subsidized loans can still borrow unsubsidized loans up to the overall maximum (e.g., $\$ 5500$ for freshmen dependent students and $\$ 9500$ for freshmen independent students). Unsubsidized loans begin accruing interest immediately after disbursement, but interest rates for both subsidized and unsubsidized loans are fixed over the lifetime of repayment.
} 
amount offered. Students who receive nonzero loan offers must still accept the offer, and new borrowers must also complete federal requirements (entrance counseling and a Master Promissory Note) in order to receive their desired aid. Students who do not receive a loan offer (or receive a $\$ 0$ offer) can still request a loan, with the specific request process varying across institutions. Nearly all four-year institutions offer students the maximum amount of loan aid for which they are eligible. Community college students are roughly evenly split between colleges that offer loans and colleges that do not (Marx and Turner 2019).

\section{$2.2 \quad \mathrm{LACC}$}

We contacted LACC based on its relatively large student body. LACC had a 12-month fulltime equivalent enrollment (FTE) of approximately 31,000 in 2014, compared to 4,300 at the average community college. Financial aid receipt is similar between LACC students and community college students nationwide. For instance, approximately 54 percent of LACC students received Pell Grant aid and 15 percent received federal loans in 2014, compared to 41 and 19 percent of students at the average community college.

LACC offers subsidized loans to all students with unmet need who are eligible for federal loan aid. Prospective students who listed LACC on their FAFSA received information relating to their financial aid packages electronically via a web-based system. An example financial aid award letter from the year of the intervention appears in Figure 1. All students were offered the maximum amount of subsidized loan for which they were eligible. In addition to federal requirements, LACC required students to actively confirm that they wish to borrow and specify the amount of loan aid they would like via an electronic loan request form. New borrowers had to complete federal entrance counseling and a Master Promissory Note. Only a subset of LACC students were eligible for unsubsidized loans, and these students were required to complete and submit a request for the additional loan aid to the LACC financial aid office in person 12

\footnotetext{
${ }^{12}$ During the year of the intervention, LACC was participating in a Department of Education initiative
} 


\section{The Experiment}

The experiment was implemented prior to the start of the 2016-17 academic year and entailed random assignment of emails to students who had not yet chosen whether to borrow. Prior to the intervention, LACC students received information about their cost of attendance, available grant aid, and subsidized federal loan offers through an electronic financial aid award letter. All students were offered the maximum amount of subsidized federal loan aid for which they were eligible. In late August 2016, the LACC financial aid office identified students who had not yet made a student loan choice. These students were assigned to either the control group or one of three treatment groups. Randomization was stratified by EFC bins and all possible combinations of binary variables for new vs. returning, freshman vs. sophomore, dependent vs. independent, and with vs. without outstanding student loan debt 13

Table 1 displays the characteristics of students in the LACC experimental sample in comparison to the nationally representative sample of community college students from the 2016 National Postsecondary Student Aid Study (NPSAS) who were enrolled during the 2015-16 academic year. LACC students are similar to the nationally representative sample in terms of gender and class standing, but they are less likely to be white (34 versus 69 percent) and more likely to be black or Hispanic (44 versus 22 percent and 39 versus 25 percent, respectively). LACC students are substantially more likely to be eligible for a Pell Grant (92 versus 23 percent) and have lower average EFCs (\$1409 versus $\$ 4268)$ but ultimately have similar levels of financial need. LACC students are less likely to have borrowed in the past only 16 percent had any outstanding student loan debt at baseline compared to 37 percent of community college students nationwide - and have lower average balances of outstanding debt ( $\$ 766$ versus $\$ 5062)$. Following this trend, during the fall semester, only 14 percent of

that allowed schools to limit unsubsidized borrowing for specific subsets of students.

${ }^{13}$ Break points for stratification by EFC were determined within combination of the binary variables so as to roughly equate the number of students per strata based on data from the two preceding years. A separate category was created for the considerable number of students with a zero EFC, and the break points always included the $\$ 5234$ threshold for Pell Grant eligibility in the 2016-17 academic year. 
LACC students borrowed, while 24 percent of community college students nationwide took up a federal loan. LACC students earned lower academic-year GPAs (2.392 versus 2.765) but graduated at similar rates as students in the national sample (15 versus 16 percent).

Panel A of Figure 2 displays the email sent to students assigned to the control group. Panel B contains the additional text in the emails sent to students in the three treatment groups. The additional text was displayed in a third separate paragraph at the end of the message.

\section{Empirical Framework}

The random assignment of students to treatments $T_{i}$ allows us to obtain causal estimates from ordinary-least-squares (OLS) regressions of the form:

$$
Y_{i}=\alpha+\beta_{1} T 1_{i}+\beta_{2} T 2_{i}+\beta_{3} T 3_{i}+\epsilon_{i}
$$

In equation (1), we examine outcome $Y_{i}$ as a function of the treatment dummy variables: $T 1_{i}$ for the reminder that one can borrow an amount other than that listed in the award letter, $T 2_{i}$ for the reminder and the reference to graduates' conditional borrowing average of $\$ 3000$, and $T 3_{i}$ for the reminder and the reference to graduates' unconditional borrowing average of $\$ 800$. In this regression, the constant $(\alpha)$ captures the average value of the outcome in the control group, and the $\beta$ coefficients capture the differences between average outcomes of each treatment group and the control group. Estimated standard errors are robust to heteroskedasticity.

Our primary outcomes describe the amount that students choose to borrow. The first is a dummy variable indicating whether the student borrowed and the second is the amount of loan aid, including values of zero. Our third borrowing outcome is a dummy variable that indicates whether the student borrowed the maximum available loan. This indicator is intended to capture whether there is any type of response to the treatments, all of which are 
expected to push students in the direction of borrowing less than the offered maximum.

In addition to equation (11), we estimate regressions of the form:

$$
Y_{i}=\alpha+\beta\left(T 2_{i}+T 3_{i}\right)+\epsilon_{i}
$$

We employ equation 2 to test for an effect of having any reference dollar amount listed in the email. Equation 2 offers greater precision than equation (1) if $\beta_{1}=0$, a hypothesis that we test after estimating equation (1). That is, if the reminder of the possibility of borrowing less than the maximum amount has no effect on students' borrowing decisions, then the most efficient estimator of average effects of reference-point treatments compares students in these treatment arms to students in treatment arms without reference points. If reference-point treatments have the same effect $\left(\beta_{2}=\beta_{3}\right)$, then pooling also provides a more efficient estimate of this effect than estimating the effect of either reference-point treatment separately.

None of the treatments has a significant effect on enrollment. Of the sample that was sent emails, 89 percent enrolled at LACC, and we find no significant effects of treatment group assignment on enrollment: $p$-values all exceed 0.38 for individual treatments and are larger than 0.90 when comparing the reference-point treatment arms to the other arms. The 95 percent confidence interval for the pooled reference point treatment specification excludes effects larger in magnitude than a 1 percentage point (1.1 percent) increase or decrease in the probability of enrollment. Thus, it does not appear that enrolled students constitute a sample that is selected on treatment status, and hence we limit the sample in our main analysis to students who enrolled at LACC and could thereby obtain a loan that is observable in the data. In an appendix, we show that our estimates are robust to including all students in the initial randomization sample, thereby including students who could not borrow from LACC but may have borrowed at a different institution.

To obtain evidence on on mechanisms, we test for heterogeneity in the treatment effect. To conduct these tests with maximal statistical power, we utilize equation 2. We jointly 
estimate this equation for partitions of the sample and then test for equality of effects across equations. For example, we split the sample into dependent students and independent students, estimate equation 2 for each of these subsamples, and test for equality of effects between the two samples.

Table 2 provides evidence that predetermined student characteristics are balanced across treatment arms. Balance is to be expected for inputs to the stratification (e.g., freshman, independent, new to LACC, prior borrowing, and EFC), but it also holds for other baseline characteristics including gender, race/ethnicity, financial need, and measures baseline attainment (credits earned and cumulative GPA). As would be expected for the number of characteristics and treatments over which we test sample balance, we find only a few differences that are statistically significant when tested individually; students in treatments T1 and T2 were about 3 percentage points more likely to be female than students in the control group; and students in treatment T4 received their financial aid package on average 1.4 days earlier than the control group. An overall F-test of joint significance of the treatments fails to reject a balanced sample for any of the baseline characteristics, and we find that controlling for baseline characteristics does not materially affect our estimates. 14

\section{$5 \quad$ Results}

In this section, we first present estimated treatment effects on borrowing outcomes. Next we provide evidence suggesting choice overload is the most consistent explanation for our main results. In particular, we estimate whether treatments affect the number of students who make active choices about their loans, and we examine heterogeneity in treatment effects. Finally, we examine treatment effects on measures of academic attainment.

\footnotetext{
${ }^{14}$ Appendix Table A.1 shows that baseline characteristics are balanced in the initial randomization sample.
} 


\subsection{Borrowing outcomes}

Table 3 displays our estimates for borrowing outcomes. Within the control group, 14 percent of students take out a loan, 12 percent borrow the maximum, and the unconditional mean amount borrowed is $\$ 496$ (Panel A). Panel B shows the estimated effects of each treatment on students' borrowing outcomes. The reminder that a student can borrow an amount other than the offered maximum (treatment $T 1$ ) has no significant effects on borrowing. However, the treatments that reference a specific dollar amount borrowed by past graduates significantly affect student borrowing.

Both reference-point treatments reduced the average amount borrowed by about $\$ 65$. As would be expected in this setting, in which the maximum available loan amount was offered in students' financial aid award letters, the reduction in borrowing is due to a reduction in the share of students who borrow the maximum, a change of roughly 1.5 percentage points for each reference-point treatment. Less expected, we find changes of similar magnitude in the share of students who take up any nonzero amount of loan aid. For both referencepoint treatments, students do not appear to shift towards the intermediate loan amounts referenced in the email, but rather to switch to not borrowing at all. This can be seen in Figure 4, which shows each treatment group's distribution of loan amounts that are strictly between zero and the student's maximum available loan. The figure shows that students in the reference-point treatments are not induced to borrow the referenced amount or other amounts near it.

Table 3 also shows the results from tests of the equality of effects across treatments. Our tests of equal effects of the two reference point treatments - T2 and T3 - produce $p$-values above 0.5 for all three loan outcomes. In contrast, we can reject a test of the equality of all three treatments with $p<0.05$ in the case of effects on borrowing and $p<0.1$ in the case of effects on the amount borrowed. Taken together, these results indicate that the reminder that a student can borrow less than the maximum available loan does not affect borrowing, but both emails with reference points describing borrowing among past students were equally 
likely to lead a student to not borrow at all.

We proceed by estimating models that combine the reference-point treatments (i.e., equation 22). These models provide greater precision when the reference-point treatments have similar effects and the reminder treatment has no effect, as we found and reported in Table 3. Estimates appear in the bottom panel of Table 3. Comparing the reference-point treatment effects to control group means, we find that emails that referenced amounts borrowed by past students reduced loan take-up by 11 percent (1.6 percentage points; $p<0.01$ ), the average amount borrowed by 13 percent $(\$ 65 ; p<0.01)$, and the probability of borrowing the maximum available loan by 12 percent (1.4 percentage points; $p<0.01$ ).

The estimated effects of the reference point treatment are robust to the inclusion of additional controls and FAFSA filers who did not enroll in LACC. Panel A of Table 4 replicates our main estimates from Table 3 . Panel B displays estimates from specifications that include additional controls for randomization strata fixed effects, while estimates in Panel C come from specifications that include controls for baseline attainment measures (whether the student is new to LACC and, for returning students, baseline cumulative credits earned and GPA at LACC). Finally, Panel D displays estimates from our main specification for the sample of both enrolled LACC students and FAFSA filers that did not enroll in LACC. Point estimates are virtually the same across these four specifications for all three borrowing outcomes.

\subsection{Inaction as a Mechanism}

We next explore the extent to which the reduction in borrowing among students who received emails containing reference points can be attributed to an active choice versus a failure to make a decision. To obtain a loan, LACC students must complete federal requirements and either actively accept the amount offered in their award letter or request a different loan amount. Students may actively decline their loan offer, but students who take no action also receive no loan. We observe whether a nonborrower made an active choice or took no action, 
and we estimate treatment effects on the latter to test for choice overload.

Table 5 presents effects on whether students made an active borrowing choice. The first column replicates estimated effects on the extensive-margin of borrowing shown in the first column of Table 3. Next, we examine whether the reference-point treatments affected the probability that a student actively declined the loan offer, an action taken by 22 percent of students in the control group. We find no evidence of meaningful changes in the probability that a treated student actively declines her loan: the estimated 0.04 percentage point reduction in the probability of actively declining a loan is statistically insignificant and is less than 3 percent of the magnitude of the estimated impact on borrowing. Third, we test for treatment effects on the probability that a student made no active decision to accept or decline the loan offer. Students assigned to the reference-point treatment groups were 1.7 percentage points $(p=0.045)$ more likely to avoid making a decision. The magnitude of this effect is very similar in size to the magnitude of the estimated impact on borrowing (1.6 percentage points). Thus, it appears that many, if not all, of the students who would have borrowed in the absence of the reference-point treatment did not actively choose to decline their loan offers but rather avoided making any decision. That financial information intended to provide guidance would instead cause inaction offers a cautionary finding for colleges and governments.

\section{$5.3 \quad$ Heterogeneity}

Next, we test whether emails had heterogeneous effects across student subgroups. We first examine subgroups defined by baseline characteristics used for stratification in random assignment: past experience of borrowing (any outstanding debt versus no outstanding debt), student resources (Pell Grant eligible versus ineligible), prior LACC enrollment (new versus returning), class standing (freshman versus sophomore status, as determined by 30-credit threshold), and dependency status. To do so, we jointly estimate equation (1) for each of ten subgroups of students and then test for equality of effects across equations. Table 6 
contains these results.

We find two dimensions along which the effects of the reference-amount treatment are statistically distinguishable between stratification subgroups. First, we find large differences in the borrowing response to seeing an explicit loan amount in the reminder email when splitting the sample by whether a student had borrowed in the past. Differences in reductions in the probability that a student borrows, the amount borrowed, and the probability of borrowing the maximum available amount due to reference-point treatments are economically and statistically larger in magnitude for past borrowers than for students who have not borrowed before. The reference-point treatments decreased borrowing by 9.2 percentage points and $\$ 362$ among past borrowers and by only 1.0 percentage points and $\$ 40$ among students with no outstanding debt 15 If students who have borrowed in the past have more information about their federal loan eligibility, then the relatively large effects on these students would be inconsistent with our finding of no effect from the information-only treatment. Rather, it appears that there are students who simply accept the number they see, which was the maximum available loan in the past for LACC students, unless they are presented with more than one amount.

The email referencing an explicit dollar amount also had significantly larger effects on borrowing for independent students than for dependent students. Differences in effects on the probability of borrowing and amount borrowed are both statistically significant at the 5 percent level, while the difference in effects on the share borrowing the maximum available loan amount are marginally significant $(p=0.055)$. This dimension of heterogeneity is consistent with dependent students being more likely to have someone with whom to discuss their borrowing choice (e.g., a parent or high school guidance counselor) than independent students, resulting in independent students being more susceptible to choice overload. These patterns of effects by both dependency and past borrowing status are quite similar to those

\footnotetext{
${ }^{15}$ We can reject tests of the equality of treatment effects by past borrowing for all three outcomes; $p$ values equal 0.008 (any borrowing), 0.009 (amount borrowed), and 0.022 (borrowing the maximum available amount).
} 
produced by the loan-offer nudges examined by Marx and Turner (2019), providing further evidence of the characteristics of students who have trouble choosing a loan amount and instead simply adhere to the amount listed in the financial aid award letter ${ }^{16}$

Next, we test for heterogeneous effects by baseline GPA. If a student's GPA serves as a proxy for her cognitive ability, and if the effect of reference-point emails operates through choice overload, then students with low baseline GPAs should exhibit larger borrowing responses to these emails. This is indeed what we find. Table 7 shows that effects are concentrated among those with below-median baseline GPAs ${ }^{17}$ The reference-point treatments reduce the share of low-GPA students borrowing by 2.8 percentage points $(p<0.01)$, while effects on high-GPA students are small, positive, and statistically insignificant. Likewise, the amount borrowed falls by a statistically significant $(p<0.01) \$ 106$ among low-GPA students who received a reference point email and the share of low-GPA students borrowing the maximum available loan decreases by a statistically significant 2.3 percentage points $(p<0.01)$, while effects on these outcomes among high-GPA students are positive and insignificant. We can reject a test of the equality of treatment effects by baseline GPA with $p \leq 0.02$ across each of the three borrowing outcomes ${ }^{18}$

Choice overload appears to provide a better explanation for our results than alternative explanations. For example, it is possible that a reference to past graduates and their debt reduces borrowing by increasing the salience of debt repayment. In this case, we might

\footnotetext{
${ }^{16}$ Appendix Table A.2 provides corresponding estimates of heterogeneity in treatment effects on the probability of actively declining a loan offer and inaction. In all cases, treatment effects on the probability of inaction are larger in magnitude than treatment effects on the probability of being an active nonborrower, and there are no subgroups for which we find significant treatment effects on the probability that a student actively declines her loan. New students are significantly more likely to respond to reference-point treatments through inaction than returning students $(4.1$ versus 0.8 percent point increases; $p=0.085)$. None of the other differences in treatment effects on inaction between subgroups are statistically significant at conventional levels, but patterns are generally consistent with inexperienced and lower-income students being more likely to experience choice overload.

${ }^{17}$ Because a student's GPA is correlated with the number of classes she has taken, we calculate the median GPA for each level of baseline cumulative credits earned and split the sample of returning students by above versus below median.

${ }^{18}$ Appendix Table A.3 shows that while low-GPA students are more likely to respond to the reference-point treatments with inaction than high ability students, the difference in treatment effects is not statistically significant $(p=0.105)$.
} 
expect larger treatment effects among forward-looking students, but we find larger effects among low-performing students who are likely less forward-looking. Moreover, the salience explanation is not consistent with the null effects obtained in debt letter experiments, where the information provided to students focused on the link between borrowing and post-college payments (Schmeiser et al. 2017, Darolia and Harper 2018). We find no evidence that students shift their borrowing towards the referenced amounts, as would be predicted by models with anchoring or students updating their beliefs about the optimal loan amount (Figure 4). Rather, it appears most likely that introducing a second concrete option for students to consider increased the likelihood of inaction.

\subsection{Attainment Effects}

Borrowing can increase educational attainment if students are liquidity constrained or face trade-offs between working and studying (Lochner and Monge-Naranjo 2012). Recent studies provide evidence of positive average effects of student loans on educational attainment for students who borrow when they have access to loans (Dunlop 2013; Wiederspan 2016; Solis 2017). Nudges that reduce borrowing can have negative effects on attainment (Barr et al. 2017; Marx and Turner 2019). Given our finding that information about past students' average borrowing also led to a significant reduction in loan take-up, we also test for effects on educational attainment.

As discussed in Section 4, we can rule out all but negligible effects of our experimental treatments on the likelihood that a student enrolls in LACC for the fall semester. Because our experimental treatments have relatively small effects on borrowing patterns, we would not expect large effects on in-college attainment, even if changes in borrowing have large effects on attainment among students who respond to the treatments. For completeness, however, we proceed to estimate effects of emails on educational attainment, as measured by credits attempted, credits earned, grade point average, and degree receipt. In Appendix Table A.4, we provide these estimates for the pooled reference-point treatments that significantly 
affected borrowing.

We find no statistically significant effects on any of these measures of attainment The confidence intervals for these estimates are large, and so the lack of statistical significance should not be taken as evidence about the attainment effects of loan aid 20 The observed reductions in borrowing may also reduce attainment and therefore may not be in the best interest of students. Students may be better served by information or assistance tailored to their individual circumstances, particularly if they fall within one of the categories of students who appear to be overwhelmed by the student loan decision.

\section{Conclusion}

We experimentally test the effect of informational emails on community college students' borrowing decisions. Randomly assigned reminders that students could borrow less than the amount listed in the financial aid award letter do not affect borrowing decisions. However, when this information is combined with a reference to the average amount borrowed by past graduates, students are less likely to borrow at all. These letters referencing amounts of past borrowing, rather than providing a helpful recommendation, appear to have induced choice overload, as the reduction in borrowing is driven by a reduction in the likelihood a student makes any decision about their loan offers, rather than an increase in the probability a student actively declines her loan. Consistent with this interpretation, effects were concentrated among independent students and those with lower academic ability.

A non-negligible share of students appears overwhelmed by choosing how much to borrow, a key decision for human capital investment. While these students appear to know that they do not have to borrow the listed amount, many do so anyway, and those affected by treatments referencing the amounts borrowed by comparable peers appear unsure of how

\footnotetext{
${ }^{19}$ There are also no effects that are significant at the 0.05 level when we separate each individual treatment (Appendix Table A.5.

${ }^{20}$ We cannot rule out effects of borrowing that are of similar magnitude to those found in our prior work (Marx and Turner 2019), such as a 0.9 additional credits earned and 0.16 higher GPAs per $\$ 1000$ borrowed.
} 
much to borrow. For colleges and the U. S. Department of Education, these results suggest that when it comes to decisions about student loans, simply providing information may not be sufficient to improve student outcomes.

The nature of the choice over student loan amounts makes policy prescription difficult, but our results offer some suggestions. Besedeš et al. (2015) show that in the lab, choice overload can be reduced by placing options in a tournament so that individuals consider a smaller number of options at any given time, but it would be difficult to implement such a tournament when the choice involves a continuous measure such as loan amount. Following this logic and our results, though, we speculate that a budgeting exercise in which students consider their expected sources of income and expected expenses would help them identify their expected financial need and choose an appropriate loan amount. Future work could explore interventions that assist or require active choice. For researchers, our results suggest caution in drawing welfare conclusions from the observed choices of students. In particular, models of rational, forward-looking borrowing may be misspecified and may give misleading impressions of students' need for credit.

\section{References}

Abaluck, Jason and Jonathan Gruber, "Choice Inconsistencies Among the Elderly: Evidence From Plan Choice in the Medicare Part D Program," American Economic Review, 2011, 101 (4), $1180-1210$.

Abraham, Katharine, Emel Filiz Ozbay, Erkut Ozbay, and Lesley J. Turner, "Framing Effects, Earnings Expectations, and the Design of Student Loan Repayment Schemes," 2018. NBER Working Paper 24484.

Akers, Elizabeth J. and Matthew M. Chingos, "Are College Students Borrowing Blindly?," https://www.brookings.edu/wp-content/uploads/2016/06/ are-college-students-borrowing-blindly_dec-2014.pdf 2014. Brown Center on Education Policy at Brookings.

Anderson, Drew M., Johnathan G. Conzelmann, and T. Austin Lacy, "The State of Financial Knowledge in College: New Evidence from a National Survey," 2018. RAND Working Paper WR-1256.

Avery, Christopher and Sarah Turner, "Student Loans: Do College Students Borrow Too Much - Or Not Enough?," Journal of Economic Perspectives, 2012, 26 (1), 165-192. 
Barr, Andrew, Kelli Bird, and Benjamin L. Castleman, "Prompting Active Choice Among High-Risk Borrowers: Evidence from a Student Loan Counseling Experiment," 2017. EdPolicyWorks Working Paper.

Benartzi, Shlomo and Richard H. Thaler, "Naive Diversification Strategies in Defined Contribution Saving Plans," American Economic Review, 2001, 91 (1), 79-98.

Besedeš, Tibor, Cary Deck, Sudipta Sarangi, and Mikhael Shor, "Reducing Choice Overload Without Reducing Choices," Review of Economics and Statistics, 2015, 97 (4), 793-802.

Bettinger, Eric P., Bridget Terry Long, Philip Oreopolous, and Lisa Sanbonmastu, "The Role of Simplification and Information in College Decisions: Results from the H\&R Block FAFSA Experiment," Quarterly Journal of Economics, 2012, 127 (3), 1205-1242.

Bhargava, Saurabh, George Loewenstein, and Shlomo Benartzi, "The costs of poor health (plan choices) \& prescriptions for reform," Behavioral Science $\&$ Policy, 2017, 3 (1), 1-12.

Booij, Adam S., Edwin Leuven, and Hessel Oosterbeek, "The Role of Information in the Take-up of Student Loans," Economics of Education Review, 2012, 31, 33-44.

Buturak, Gökhan and Özgür Evren, "Choice Overload and Asymmetric Regret," Theoretical Economics, 2017, 12 (3), 1029-1056.

Cadena, Brian C. and Benjamin J. Keys, "Can Self-Control Explain Avoiding Free Money? Evidence from Interest-Free Student Loans," Review of Economics and Statistics, 2013, 95 (4), 1117-1129.

Caetano, Gregorio, Miguel Palacios, and Harry Anthony Patrinos, "Measuring Aversion to Debt: An Experiment among Student Loan Candidates," 2011. World Bank Policy Research Working Paper No. 5737.

Chernev, Alexander, Ulf Böckenholt, and Joseph Goodman, "Choice Overload: A Conceptual Review and Meta-Analysis," Journal of Consumer Psychology, 2015, 25 (2), 333-358.

Cox, James C., Daniel Kreisman, and Susan Dynarski, "Designed to Fail: Effects of the Default Option and Information Complexity on Student Loan Repayment," 2018. NBER Working Paper 25258.

Darolia, Rajeev and Casandra Harper, "Information Use and Attention Deferment in College Student Loan Decisions: Evidence From a Debt Letter Experiment," Educational Evaluation and Policy Analysis, 2018, 40 (1).

Dunlop, Erin, "What do Stafford Loans Actually Buy You? The Effect of Stafford Loan Access on Community College Students," 2013. CALDER Working Paper 94.

Dynarski, Susan M. and Judith E. Scott-Clayton, "The Cost Of Complexity In Federal Student Aid: Lessons From Optimal Tax Theory And Behavioral Economics," National Tax Journal, 2006, 59 (2), 319-356.

Evans, Brent J., Angela Boatman, and Adela Soliz, "Framing and Labeling Effects in Preferences for Borrowing for College: An Experimental Analysis," Research in Higher Education, 2018. 
Federal Reserve Bank of New York, "Quarterly Report on Household Debt and Credit 2018: Q4," 2019. New York, NY: Federal Reserve Bank of New York.

Field, Erica, "Educational Debt Burden and Career Choice: Evidence from a Financial Aid Experiment at NYU Law School," American Economic Journal: Applied Economics, 2009, 1 (1), $1-21$.

Heiss, Florian, Daniel McFadden, and Joachim Winter, "Mind the Gap! Consumer Perceptions and Choices of Medicare Part D Prescription Drug Plans," in David A. Wise, ed., Research Findings in the Economics of Aging, University of Chicago Press, 2010, pp. 413-481.

Iyengar, Sheena S. and Emir Kamenica, "Choice Proliferation, Simplicity Seeking, and Asset Allocation," Journal of Public Economics, 2010, 94 (7-8), 530-539.

- and Mark R. Lepper, "When Choice is Demotivating: Can One Desire Too Much of a Good Thing?," Journal of Personality and Social Psychology, 2000, 79 (6), 995-1006.

_, Gur Huberman, and Wei Jiang, "How Much Choice is Too Much? Contributions to 401(k) Retirement Plans," in Olivia S. Mitchell and Stephen P. Utkus, eds., Pension Design and Structure: New Lessons from Behavioral Finance, Oxford University Press Inc., New York, 2004, pp. $84-87$.

Johnson, Eric J, Ran Hassin, Tom Baker, Allison T Bajger, and Galen Treuer, "Can Consumers Make Affordable Care Affordable? The Value of Choice Architecture," PloS one, 2013, 8 (12), e81521.

Kairies-Schwarz, Nadja, Johanna Kokot, Markus Vomhof, and Jens Wessling, "How Do Consumers Choose Health Insurance?-An Experiment on Heterogeneity in Attribute Tastes and Risk Preferences," 2014. Ruhr Economic Paper No. 537.

Kuksov, Dmitri and J. Miguel Villas-Boas, "When More Alternatives Lead to Less Choice," Marketing Science, 2010, 29 (3), 507-524.

Lochner, Lance and Alexander Monge-Naranjo, "Credit Constraints in Education," Annual Review of Economics, 2012, 4 (1), 225-256.

Looney, Adam and Constantine Yannelis, "A Crisis in Student Loans?: How Changes in the Characteristics of Borrowers and in the Institutions They Attended Contributed to Rising Loan Defaults," Brookings Papers on Economic Activity, 2015, pp. 1-89.

Lusardi, Annamaria, Carlo de Bassa Scheresberg, and Noemi Oggero, "Student Loan Debt in the US: An Analysis of the 2015 NFCS Data," https://www . usfinancialcapability. org/downloads/GFLEC-Brief-Student-Loan-Debt.pdf 2016. Global Financial Literacy Excellence Center Policy Brief.

Marx, Benjamin M. and Lesley J. Turner, "Borrowing Trouble? Student Loans, the Cost of Borrowing, and Implications for the Effectiveness of Need-Based Grant Aid," American Economic Journal: Applied Economics, 2018, 10 (2), 163-201.

_ and _ , "Student Loan Nudges: Experimental Evidence on Borrowing and Educational Attainment," American Economic Journal: Economic Policy, 2019, 11 (2), 108-141. 
Pallais, Amanda, "Small Differences that Matter: Mistakes in Applying to College," Journal of Labor Economics, 2015, 33 (2), 493-520.

Sarver, Todd, "Anticipating Regret: Why Fewer Options May Be Better," Econometrica, 2008, $76(2), 263-305$.

Scheibehenne, Benjamin, Rainer Greifeneder, and Peter M. Todd, "Can There Ever Be Too Many Options? A Meta-Analytic Review of Choice Overload," Journal of Consumer Research, 2010, 37 (3), 409-425.

Schmeiser, Maximilian, Christina Stoddard, and Carly Urban, "Does Salient Student Loan Information College Students' Academic and Borrowing Behavior?," Economics of Education Review, 2017, 56, 95-109.

Schram, Arthur and Joep Sonnemans, "How Individuals Choose Health Insurance: An Experimental Analysis," European Economic Review, 2011, 55 (6), 799-819.

Shafir, Eldar, Itamar Simonson, and Amos Tversky, "Reason-based Choice," Cognition, 1993, 49, 11-36.

Solis, Alex, "Credit Access and College Enrollment," Journal of Political Economy, 2017, 125 (2), $562-622$.

Stoddard, Christina and Carly Urban, "The Effects of State Mandated Financial Education on College Financing Behaviors," Journal of Money, Credit, and Banking, forthcoming.

Wiederspan, Mark, "Denying Loan Access: The Student-Level Consequences When Community Colleges Opt Out of the Stafford Loan Program," Economics of Education Review, 2016, 51, $79-96$.

Zhou, Chao and Yuting Zhang, "The Vast Majority Of Medicare Part D Beneficiaries Still Don't Choose The Cheapest Plans That Meet Their Medication Needs," Health Affairs, 2012, 31 (10), 2259-2265. 


\section{Figures and Tables}

Figure 1: Financial Aid Award Letter for Hypothetical Student "Finny Aid"

\begin{tabular}{|l}
\hline Financial Aid Awards Status \\
2015: (Fall 2014 - Summer 2015) \\
Welcome Finny Aid
\end{tabular}

Your initial award is based on full time enrollment. Credited amount is based on your current enrollment. If your enrollment changes, your awards will be adjusted accordingly. Future sessions will be disbursed later in the term.

To Accept/Decline/Reduce your Direct Subsidized Loan you must visit the Financial Aid "Application Status" screen.

\begin{tabular}{|c|c|c|c|c|c|c|}
\hline \multirow{2}{*}{$\begin{array}{c}\text { Awards by Term } \\
\text { Financial Aid }\end{array}$} & \multicolumn{2}{|c|}{ Fall } & \multicolumn{2}{|c|}{ Winter } & \multicolumn{2}{|c|}{ Summer } \\
\hline & Award & Credited & Award & Credited & Award & Credited \\
\hline DIRECT LOAN SUBSIDIZED & $\$ 750.00$ & & $\$ 750.00$ & & & \\
\hline Federal Pell Grant & $\$ 2,865.00$ & & $\$ 2,865.00$ & & & \\
\hline Total all awards & $\$ 3,615.00$ & & $\$ 3,615.00$ & & & \\
\hline
\end{tabular}

Figure 2: Control Group Email

An important email from your $\quad$ Financial Aid Office

YOUR ID\#:

Dear

Don't forget, your estimated financial aid package for 2016-17 has been posted to your account.

Please make your student loan decision by Tuesday, September 6. You can accept, decline, or alter the Federal Direct Subsidized loan offer you have received by logging in to -> Financial Aid -> Application Status and select the Accept/ Decline loan document.

Have a wonderful and successful year!

Office of Financial Aid

For more information please visit the financial aid website a 
Figure 3: Additional Text in Treatment Group Emails

\begin{tabular}{|l|l|}
\hline Treatment arm & Additional text \\
\hline \hline 1. Information & $\begin{array}{l}\text { The amount of Federal Direct Subsidized loan offered in } \\
\text { your award letter is the maximum amount you are eligible } \\
\text { to borrow through the program. You do not have to } \\
\text { borrow this full amount. Log into [online portal] if you } \\
\text { wish to reduce or decline your loan. }\end{array}$ \\
\hline 2. Information + high reference point & $\begin{array}{l}\text { The amount of Federal Direct Subsidized loan offered in } \\
\text { your award letter is the maximum amount you are eligible } \\
\text { to borrow through the program. You do not have to } \\
\text { borrow this full amount. Last school year, the average } \\
\text { subsidized loan borrower who graduated borrowed about } \\
\text { \$3000. Log into [online portal] if you wish to reduce or } \\
\text { decline your loan. }\end{array}$ \\
\hline 3. Information + low reference point & $\begin{array}{l}\text { The amount of Federal Direct Subsidized loan offered in } \\
\text { your award letter is the maximum amount you are eligible } \\
\text { to borrow through the program. You do not have to } \\
\text { borrow this full amount. Last school year, the average } \\
\text { student who graduated borrowed about \$800. Log into } \\
\text { [online portal] if you wish to reduce or decline your loan. }\end{array}$ \\
\hline
\end{tabular}

Figure 4: Distribution of Loans by Treatment Group for Students Borrowing Less than the Maximum Available Loan

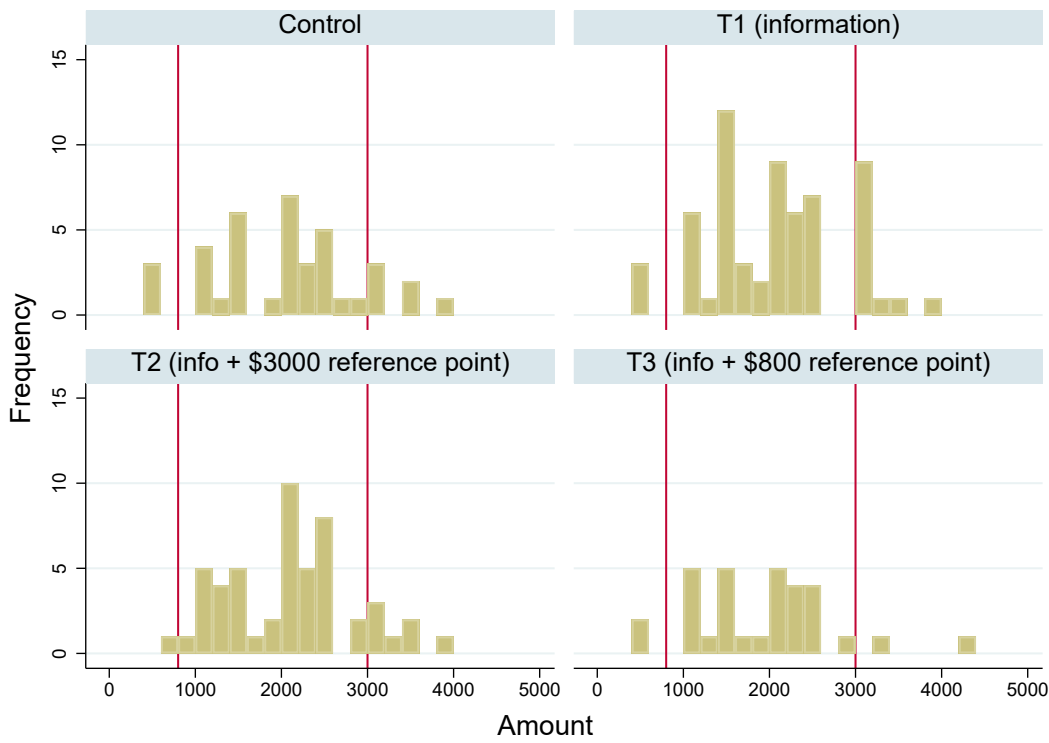

Notes: LACC experimental sample students who borrowed a positive amount that was less than the maximum amount available to the student $(\mathrm{N}=181)$. 
Table 1: Summary Statistics

\begin{tabular}{lcc}
\hline & $\begin{array}{c}\text { LACC experimental } \\
\text { sample }\end{array}$ & $\begin{array}{c}2016 \text { NPSAS CC } \\
\text { students }\end{array}$ \\
\hline $\begin{array}{l}\text { A. Demographics } \\
\text { Freshman }\end{array}$ & 0.47 & 0.52 \\
Gender = female & 0.59 & 0.61 \\
Race/ethnicity & & \\
Black & 0.44 & 0.22 \\
Hispanic & 0.39 & 0.25 \\
$\quad$ White & 0.34 & 0.69 \\
Independent & 0.44 & 0.49 \\
B. Finances & & $\$ 4,268$ \\
Expected family contribution & $\$ 1,409$ & 0.23 \\
Pell Grant eligible & 0.92 & $\$ 9,695$ \\
Financial need & $\$ 8,419$ & 0.37 \\
Any fed. student loan debt & 0.16 & $\$ 5,062$ \\
Outstanding federal student loans & $\$ 766$ & \\
C. Outcomes & & 0.24 \\
Borrowed & 0.14 & $\$ 1,169$ \\
Amount borrowed & $\$ 496$ & 0.16 \\
Academic year GPA & 2.392 & \\
Degree reciept & 0.15 & \\
\hline
\end{tabular}

Notes: LACC experimental sample students who enrolled in fall $2016(\mathrm{~N}=13,065)$ and FAFSA-filing community college students who enrolled in fall 2015 from the 2016 National Postsecondary Student Aid Study (NPSAS). Race/ethnicity categories are not mutually exclusive. 
Table 2: Balance Across Treatment Groups

\begin{tabular}{|c|c|c|c|c|c|c|c|}
\hline Dependent variable: & (1) Freshman & (2) Female & (3) Black & (4) Hispanic & (5) White & (6) Independent & $\begin{array}{l}\text { (7) New to } \\
\text { LACC }\end{array}$ \\
\hline Sample mean & 0.624 & 0.586 & 0.424 & 0.396 & 0.347 & 0.420 & 0.258 \\
\hline $\mathrm{T} 2(\mathrm{~T} 1+\$ 3000$ ref. point $)$ & $\begin{array}{l}0.0002 \\
(0.012)\end{array}$ & $\begin{array}{c}0.028 \\
(0.012)^{*}\end{array}$ & $\begin{array}{l}-0.003 \\
(0.012)\end{array}$ & $\begin{array}{c}0.007 \\
(0.012)\end{array}$ & $\begin{array}{l}-0.003 \\
(0.012)\end{array}$ & $\begin{array}{l}-0.0004 \\
(0.012)\end{array}$ & $\begin{array}{c}0.002 \\
(0.011)\end{array}$ \\
\hline Constant & $\begin{array}{c}0.623 \\
(0.008)^{* *}\end{array}$ & $\begin{array}{c}0.568 \\
(0.009)^{* *}\end{array}$ & $\begin{array}{c}0.434 \\
(0.009)^{* *}\end{array}$ & $\begin{array}{c}0.386 \\
(0.009)^{* *}\end{array}$ & $\begin{array}{c}0.343 \\
(0.008)^{* *}\end{array}$ & $\begin{array}{c}0.420 \\
(0.009)^{* *}\end{array}$ & $\begin{array}{c}0.255 \\
(0.008)^{* *}\end{array}$ \\
\hline Test of joint sig. ( $p$-value) & 0.922 & 0.233 & 0.349 & 0.631 & 0.499 & 0.950 & 0.900 \\
\hline Observations & 13,065 & 13,065 & 13,065 & 13,065 & 13,065 & 13,065 & 13,065 \\
\hline Dependent variable: & (8) $\mathrm{EFC}$ & (9) Need & $\begin{array}{l}\text { (10) Prior } \\
\text { borrowing }\end{array}$ & $\begin{array}{c}\text { (11) Outst. } \\
\text { student loans }\end{array}$ & $\begin{array}{l}\text { (12) Packaged - } \\
\text { days since 6/14 }\end{array}$ & $\begin{array}{l}\text { (13) Baseline } \\
\text { credits earned }\end{array}$ & $\begin{array}{l}\text { (14) Baseline } \\
\text { GPA }\end{array}$ \\
\hline $\mathrm{T} 2(\mathrm{~T} 1+\$ 3000$ ref. point $)$ & $\begin{array}{c}34 \\
(68)\end{array}$ & $\begin{array}{c}-31.654 \\
(143.988)\end{array}$ & $\begin{array}{l}-0.002 \\
(0.006)\end{array}$ & $\begin{array}{l}-56 \\
(42)\end{array}$ & $\begin{array}{l}-1.4 \\
(0.6)^{*}\end{array}$ & $\begin{array}{l}-0.02 \\
(0.6)\end{array}$ & $\begin{array}{c}0.030 \\
(0.032)\end{array}$ \\
\hline $\mathrm{T} 3$ (T1 + \$800 ref. point) & $\begin{array}{c}-8 \\
(66)\end{array}$ & $\begin{array}{c}-97.296 \\
(142.650)\end{array}$ & $\begin{array}{c}0.002 \\
(0.007)\end{array}$ & $\begin{array}{l}-12 \\
(44)\end{array}$ & $\begin{array}{l}-0.2 \\
(0.7)\end{array}$ & $\begin{array}{l}-0.3 \\
(0.6)\end{array}$ & $\begin{array}{c}0.029 \\
(0.032)\end{array}$ \\
\hline Constant & $\begin{array}{l}1,296 \\
(47)^{* *}\end{array}$ & $\begin{array}{c}8,475.108 \\
(101.322)^{* *}\end{array}$ & $\begin{array}{c}0.075 \\
(0.005)^{* *}\end{array}$ & $\begin{array}{c}393 \\
(32)^{* *}\end{array}$ & $\begin{array}{c}44.2 \\
(0.5)^{* *}\end{array}$ & $\begin{array}{l}27.0 \\
(0.4)^{* *}\end{array}$ & $\begin{array}{c}2.579 \\
(0.023)^{* *}\end{array}$ \\
\hline Test of joint sig. ( $p$-value) & 0.788 & 0.874 & 0.811 & 0.500 & 0.143 & 0.86 & 0.946 \\
\hline Observations & 13,065 & 13,065 & 13,065 & 13,065 & 13,065 & 9,692 & 9,692 \\
\hline
\end{tabular}

Notes: LACC experimental sample students who enrolled in fall 2016. Race/ethnicity categories are not mutually exclusive. Robust standard errors in parentheses; ${ }^{* *} \mathrm{p}<0.01,{ }^{*} \mathrm{p}<0.05,+\mathrm{p}<0.1$. 
Table 3: The Impact of Information and Reference Points on Student Borrowing Outcomes

\begin{tabular}{lccc}
\hline & $\begin{array}{c}\text { (1) Any } \\
\text { borrowing }\end{array}$ & $\begin{array}{c}\text { (2) Amount } \\
\text { borrowed }\end{array}$ & $\begin{array}{c}\text { (3) Amount } \\
\max \end{array}$ \\
\hline A. Control group mean & 0.14 & 496 & 0.12 \\
& & $(1287)$ & \\
\hline $\begin{array}{l}\text { B. OLS estimates, all treatments } \\
\text { T1 (can borrow other amt) }\end{array}$ & 0.004 & -4.9 & -0.004 \\
& $(0.009)$ & $(31.6)$ & $(0.008)$ \\
T2 (T1 + \$3000 ref point) & -0.012 & -63.5 & -0.016 \\
& $(0.008)$ & $(30.7)^{*}$ & $(0.008)^{*}$ \\
T3 (T1 + \$800 ref point) & -0.017 & -68.6 & -0.015 \\
& $(0.008)^{*}$ & $(30.7)^{*}$ & $(0.008)+$ \\
Tests of equality (p- value) & & & \\
All treatments & 0.038 & 0.071 & 0.216 \\
T2 = T3 & 0.573 & 0.863 & 0.826 \\
Observations & 13,065 & 13,065 & 13,065 \\
\hline C. OLS estimates, pooled reference point treatments & & \\
T2 + T3 & -0.016 & -64.7 & -0.014 \\
& $(0.006)^{* *}$ & $(21.7)^{* *}$ & $(0.006)^{*}$ \\
Observations & 13,065 & 13,065 & 13,065 \\
\hline
\end{tabular}

Notes: OLS estimates of treatment effects on borrowing outcomes. Robust standard errors in parentheses; ${ }^{* *} \mathrm{p}<0.01,{ }^{*} \mathrm{p}<0.05,+\mathrm{p}<0.1$. 
Table 4: Robustness of Estimated Effects on Borrowing

\begin{tabular}{lccc}
\hline & $\begin{array}{c}\text { (1) Any } \\
\text { borrowing }\end{array}$ & $\begin{array}{c}\text { (2) Amount } \\
\text { borrowed }\end{array}$ & $\begin{array}{c}\text { (3) Amount }= \\
\max \end{array}$ \\
\hline $\begin{array}{l}\text { A. Baseline estimates } \\
\text { Pooled reference point treatments }\end{array}$ & $\begin{array}{c}-0.016 \\
(0.006)^{* *}\end{array}$ & $\begin{array}{c}-64.7 \\
(21.7)^{* *}\end{array}$ & $\begin{array}{c}-0.014 \\
(0.006)^{*}\end{array}$ \\
& 13,065 & 13,065 & 13,065 \\
Observations & & & \\
\hline B. Strata fixed effects & -0.016 & -62.4 & -0.013 \\
Pooled reference point treatments & $(0.007)^{*}$ & $(27.6)^{*}$ & $(0.007)+$ \\
& 13,065 & 13,065 & 13,065 \\
Observations & & & \\
\hline C. Controls for baseline attainment & -0.016 & -63.3 & -0.014 \\
Pooled reference point treatments & $(0.006)^{* *}$ & $(21.6)^{* *}$ & $(0.006)^{*}$ \\
& 13,065 & 13,065 & 13,065 \\
Observations & \multicolumn{3}{c}{} \\
\hline D. Initial randomization sample & -0.014 & -53.7 & -0.012 \\
$\quad$ Pooled reference point treatments & $(0.005)^{*}$ & $(19.9)^{* *}$ & $(0.005)^{*}$ \\
& 14,784 & 14,784 & 14,784 \\
\hline
\end{tabular}

Notes: For Panel A specification, see Table 3 notes. Panel B regressions include controls for randomassignment strata fixed effects. Panel C includes controls for whether the student is new to LACC, baseline credits earned, and cumulative GPA. Panel D includes observations of randomly assigned FAFSA filers that did not enroll in LACC. Robust standard errors in parentheses; ${ }^{* *} \mathrm{p}<0.01,{ }^{*} \mathrm{p}<0.05,+\mathrm{p}<0.1$.

Table 5: Reference Point Treatments Lead to a Reduction in Active Choice

\begin{tabular}{lccc}
\hline & $\begin{array}{c}\text { (1) Any } \\
\text { borrowing }\end{array}$ & $\begin{array}{c}\text { (2) Active } \\
\text { nonborrower }\end{array}$ & $\begin{array}{c}\text { (3) No } \\
\text { decision }\end{array}$ \\
\hline A. Control group mean & 0.14 & 0.22 & 0.64 \\
\hline $\begin{array}{l}\text { B. OLS estimates } \\
\text { Pooled reference point treatments }\end{array}$ & $\begin{array}{c}-0.016 \\
(0.006)^{* *}\end{array}$ & $\begin{array}{c}-0.0004 \\
(0.007)\end{array}$ & $\begin{array}{c}0.017 \\
(0.008)^{*}\end{array}$ \\
Observations & 13,065 & 13,065 & 13,065 \\
\hline
\end{tabular}

Notes: OLS estimates of treatment effects on the probability that a student accepts a loan of any amount, actively declines her loan, and does not make a borrowing decision. Robust standard errors in parentheses; ** $\mathrm{p}<0.01,{ }^{*} \mathrm{p}<0.05,+\mathrm{p}<0.1$. 
Table 6: Heterogeneous Effects by Stratification Variables

\begin{tabular}{|c|c|c|c|}
\hline & $\begin{array}{c}\text { (1) Any } \\
\text { borrowing }\end{array}$ & $\begin{array}{l}\text { (2) Amount } \\
\text { borrowed }\end{array}$ & $\begin{array}{l}\text { (3) Amount }= \\
\max \end{array}$ \\
\hline \multicolumn{4}{|l|}{ Subgroup } \\
\hline No outstanding debt $(\mathrm{N}=12,088)$ & $\begin{array}{c}-0.010 \\
(0.006)+\end{array}$ & $\begin{array}{c}-40 \\
(21)+\end{array}$ & $\begin{array}{l}-0.009 \\
(0.005)\end{array}$ \\
\hline Has outstanding debt $(\mathrm{N}=977)$ & $\begin{array}{c}-0.092 \\
(0.030)^{* *} \\
{[0.008]}\end{array}$ & $\begin{array}{c}-362 \\
(121)^{* *} \\
{[0.009]}\end{array}$ & $\begin{array}{c}-0.078 \\
(0.029)^{* *} \\
{[0.022]}\end{array}$ \\
\hline Pell eligible $(N=12,047)$ & $\begin{array}{c}-0.017 \\
(0.006)^{* *}\end{array}$ & $\begin{array}{c}-67 \\
(22)^{* *}\end{array}$ & $\begin{array}{c}-0.014 \\
(0.006)^{*}\end{array}$ \\
\hline Pell ineligible $(\mathrm{N}=1,018)$ & $\begin{array}{l}-0.005 \\
(0.023) \\
{[0.595]}\end{array}$ & $\begin{array}{c}-29 \\
(82) \\
{[0.661]}\end{array}$ & $\begin{array}{c}-0.009 \\
(0.022) \\
{[0.811]}\end{array}$ \\
\hline New student $(N=3,373)$ & $\begin{array}{c}-0.023 \\
(0.013)+\end{array}$ & $\begin{array}{c}-86 \\
(43)^{*}\end{array}$ & $\begin{array}{c}-0.023 \\
(0.012)+\end{array}$ \\
\hline Returning student $(\mathrm{N}=9,692)$ & $\begin{array}{c}-0.014 \\
(0.007)^{*} \\
{[0.522]}\end{array}$ & $\begin{array}{c}-56 \\
(25)^{*} \\
{[0.549]}\end{array}$ & $\begin{array}{c}-0.011 \\
(0.006)+ \\
{[0.792]}\end{array}$ \\
\hline$<30$ credits earned $(N=8,155)$ & $\begin{array}{c}-0.016 \\
(0.008)^{*}\end{array}$ & $\begin{array}{c}-47 \\
(27)+\end{array}$ & $\begin{array}{c}-0.013 \\
(0.007)+\end{array}$ \\
\hline 30 or more credits earned $(\mathrm{N}=4,910)$ & $\begin{array}{c}-0.018 \\
(0.009)+ \\
{[0.855]}\end{array}$ & $\begin{array}{c}-91 \\
(36)^{*} \\
{[0.327]}\end{array}$ & $\begin{array}{c}-0.016 \\
(0.008)^{* *} \\
{[0.527]}\end{array}$ \\
\hline Dependent student $(\mathrm{N}=7,575)$ & $\begin{array}{l}-0.006 \\
(0.007)\end{array}$ & $\begin{array}{l}-23 \\
(24)\end{array}$ & $\begin{array}{l}-0.004 \\
(0.006)\end{array}$ \\
\hline Independent student $(\mathrm{N}=5,490)$ & $\begin{array}{c}-0.031 \\
(0.010) * * \\
{[0.038]}\end{array}$ & $\begin{array}{c}-118 \\
(39)^{* *} \\
{[0.037]}\end{array}$ & $\begin{array}{c}-0.027 \\
(0.010)^{* *} \\
{[0.055]}\end{array}$ \\
\hline
\end{tabular}

Notes: OLS estimates of treatment effects on borrowing outcomes among subgroups. Regressions for subgroups in each row jointly estimated. Bracketed numbers contain $p$-values from tests of equality of effects between mutually exclusive subgroups. Robust standard errors in parentheses; ${ }^{* *} \mathrm{p}<0.01,{ }^{*} \mathrm{p}<0.05,+$ $\mathrm{p}<0.1$. 
Table 7: Heterogeneous Effects by Baseline Academic Performance

\begin{tabular}{cccc}
\hline & $\begin{array}{c}(1) \text { Any } \\
\text { borrowing }\end{array}$ & $\begin{array}{c}(2) \text { Amount } \\
\text { borrowed }\end{array}$ & $\begin{array}{c}(3) \text { Amount }= \\
\max \end{array}$ \\
\hline Below median baseline GPA & -0.028 & -106 & -0.023 \\
$(\mathrm{~N}=5,543)$ & $(0.009)^{* *}$ & $(34)^{* *}$ & $(0.009)^{* *}$ \\
Above median baseline GPA & 0.004 & 10 & 0.006 \\
$(\mathrm{~N}=4,149)$ & $(0.009)$ & $(36)$ & $(0.009)$ \\
& {$[0.015]$} & {$[0.020]$} & {$[0.019]$} \\
\hline
\end{tabular}

Notes: OLS estimates of treatment effects on borrowing outcomes among returning students $(\mathrm{N}=9,692)$. Regressions for above- and below-median baseline GPA jointly estimated. Bracketed numbers contain $p$ values of tests of equality of effects between the two subgroups. Robust standard errors in parentheses; $* *$ $\mathrm{p}<0.01,{ }^{*} \mathrm{p}<0.05,+\mathrm{p}<0.1$. 


\section{Appendix A: Additional Tables}

Table A.1: Balance Across Treatment Groups in Initial Sample

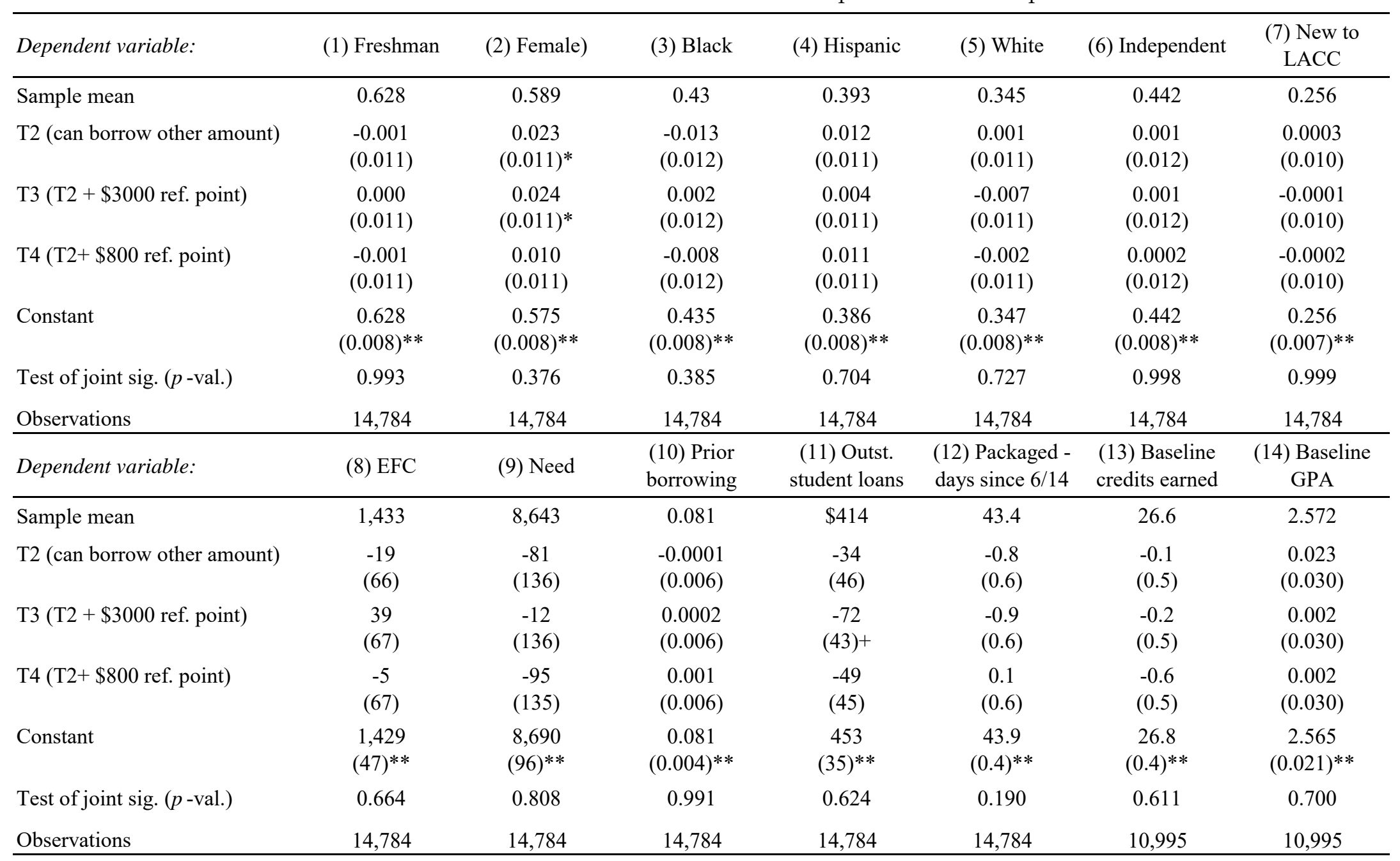

Notes: See Table 2 notes. 
Table A.2: Heterogeneous Effects on the Probability of Making an Active Choice by Stratification Variables

\begin{tabular}{|c|c|c|c|}
\hline & $\begin{array}{l}\text { (1) Any } \\
\text { borrowing }\end{array}$ & $\begin{array}{c}\text { (2) Active } \\
\text { nonborrower }\end{array}$ & $\begin{array}{l}\text { (3) No } \\
\text { decision }\end{array}$ \\
\hline \multicolumn{4}{|l|}{ Subgroup } \\
\hline No outstanding debt $(\mathrm{N}=12,088)$ & $\begin{array}{c}-0.010 \\
(0.006)+\end{array}$ & $\begin{array}{l}-0.004 \\
(0.007)\end{array}$ & $\begin{array}{c}0.014 \\
(0.009)+\end{array}$ \\
\hline Has outstanding debt $(\mathrm{N}=977)$ & $\begin{array}{c}-0.092 \\
(0.030)^{* *} \\
{[0.008]}\end{array}$ & $\begin{array}{c}0.041 \\
(0.029) \\
{[0.137]}\end{array}$ & $\begin{array}{c}0.051 \\
(0.030)+ \\
{[0.242]}\end{array}$ \\
\hline Pell eligible $(N=12,047)$ & $\begin{array}{c}-0.017 \\
(0.006)^{* *}\end{array}$ & $\begin{array}{r}-0.0001 \\
(0.008)\end{array}$ & $\begin{array}{c}0.017 \\
(0.009) *\end{array}$ \\
\hline Pell ineligible $(N=1,018)$ & $\begin{array}{l}-0.005 \\
(0.023) \\
{[0.595]}\end{array}$ & $\begin{array}{l}-0.005 \\
(0.024) \\
{[0.857]}\end{array}$ & $\begin{array}{c}0.009 \\
(0.030) \\
{[0.788]}\end{array}$ \\
\hline New student $(\mathrm{N}=3,373)$ & $\begin{array}{c}-0.023 \\
(0.013)+\end{array}$ & $\begin{array}{l}-0.018 \\
(0.013)\end{array}$ & $\begin{array}{c}0.041 \\
(0.016) *\end{array}$ \\
\hline Returning student $(\mathrm{N}=9,692)$ & $\begin{array}{c}-0.014 \\
(0.007)^{*} \\
{[0.522]}\end{array}$ & $\begin{array}{c}0.005 \\
(0.009) \\
{[0.130]}\end{array}$ & $\begin{array}{c}0.008 \\
(0.010) \\
{[0.085]}\end{array}$ \\
\hline$<30$ credits earned $(N=8,155)$ & $\begin{array}{c}-0.016 \\
(0.008)^{*}\end{array}$ & $\begin{array}{l}-0.011 \\
(0.009)\end{array}$ & $\begin{array}{c}0.027 \\
(0.010) *\end{array}$ \\
\hline 30 or more credits earned $(\mathrm{N}=4,910)$ & $\begin{array}{c}-0.018 \\
(0.009)+ \\
{[0.855]}\end{array}$ & $\begin{array}{c}0.017 \\
(0.013) \\
{[0.070]}\end{array}$ & $\begin{array}{c}0.001 \\
(0.014) \\
{[0.136]}\end{array}$ \\
\hline Dependent student $(\mathrm{N}=7,575)$ & $\begin{array}{l}-0.006 \\
(0.007)\end{array}$ & $\begin{array}{l}-0.009 \\
(0.009)\end{array}$ & $\begin{array}{l}0.015 \\
(0.010)\end{array}$ \\
\hline Independent student $(\mathrm{N}=5,490)$ & $\begin{array}{c}-0.031 \\
(0.010)^{* *} \\
{[0.038]}\end{array}$ & $\begin{array}{c}0.012 \\
(0.012) \\
{[0.165]}\end{array}$ & $\begin{array}{c}0.019 \\
(0.013) \\
{[0.784]}\end{array}$ \\
\hline
\end{tabular}

Notes: OLS estimates of treatment effects on borrowing outcomes among subgroups. Regressions for subgroups in each row jointly estimated. Bracketed numbers contain $p$-values from tests of equality of effects between mutually exclusive subgroups. Robust standard errors in parentheses; ${ }^{* *} \mathrm{p}<0.01,{ }^{*} \mathrm{p}<0.05,+$ $\mathrm{p}<0.1$. 
Table A.3: Heterogeneous Effects on the Probability of Making an Active Choice by Baseline Academic Performance

\begin{tabular}{cccc}
\hline & $\begin{array}{c}(1) \text { Any } \\
\text { borrowing }\end{array}$ & $\begin{array}{c}(2) \text { Active } \\
\text { nonborrower }\end{array}$ & $\begin{array}{c}(3) \text { No } \\
\text { decision }\end{array}$ \\
\hline Below median baseline GPA & -0.028 & -0.001 & 0.024 \\
$(\mathrm{~N}=5,543)$ & $(0.009)^{* *}$ & $(0.012)$ & $(0.014)+$ \\
Above median baseline GPA & 0.004 & 0.013 & -0.007 \\
$(\mathrm{~N}=4,149)$ & $(0.009)$ & $(0.013)$ & $(0.014)$ \\
& {$[0.015]$} & {$[0.428]$} & {$[0.105]$} \\
\hline
\end{tabular}

Notes: OLS estimates of treatment effects on borrowing outcomes among returning students $(\mathrm{N}=9,692)$. Regressions for above- and below-median baseline GPA jointly estimated. Bracketed numbers contain $p$ values of tests of equality of effects between the two subgroups. Robust standard errors in parentheses; $* *$ $\mathrm{p}<0.01,{ }^{*} \mathrm{p}<0.05,+\mathrm{p}<0.1$.

Table A.4: The Impact of Nonzero Loan Offers on Attainment

\begin{tabular}{lcccc}
\hline & $\begin{array}{c}\text { (1) Credits } \\
\text { attempted }\end{array}$ & $\begin{array}{c}\text { (2) Credits } \\
\text { earned }\end{array}$ & (3) GPA & $\begin{array}{c}\text { (4) Earned } \\
\text { degree }\end{array}$ \\
\hline T2 (can borrow other amt) & -0.181 & -0.311 & -0.050 & -0.014 \\
& $(0.174)$ & $(0.190)$ & $(0.028)+$ & $(0.009)+$ \\
T3 (T2 + \$3000 ref point) & 0.071 & 0.021 & 0.001 & -0.008 \\
& $(0.175)$ & $(0.189)$ & $(0.027)$ & $(0.009)$ \\
T4 (T2 + \$800 ref point) & 0.028 & 0.023 & -0.010 & -0.014 \\
& $(0.174)$ & $(0.188)$ & $(0.027)$ & $(0.009)$ \\
Tests of equality $(p$ - val) & & & & \\
All treatments & 0.300 & 0.127 & 0.154 & 0.693 \\
T3 = T4 & 0.806 & 0.990 & 0.673 & 0.483 \\
Observations & 13,065 & 13,065 & 13,065 & 13,065 \\
\hline
\end{tabular}

Notes: See Table 3 notes.

Table A.5: The Impact of Nonzero Loan Offers on Attainment

\begin{tabular}{lcccc}
\hline & $\begin{array}{c}\text { (1) Credits } \\
\text { attempted }\end{array}$ & $\begin{array}{c}\text { (2) Credits } \\
\text { earned }\end{array}$ & (3) GPA & $\begin{array}{c}\text { (4) Earned } \\
\text { degree }\end{array}$ \\
\hline $\begin{array}{lccc}\text { A. Control group mean } \\
15.8\end{array}$ & $\begin{array}{c}12.7 \\
(7.1)\end{array}$ & $\begin{array}{c}2.392 \\
(1.112)\end{array}$ & 0.15 \\
\hline $\begin{array}{l}\text { B. OLS estimates } \\
\text { Pooled reference point treatments }\end{array}$ & 0.140 & 0.177 & 0.021 & -0.004 \\
& $(0.123)$ & $(0.133)$ & $(0.019)$ & $(0.006)$ \\
Observations & 13,065 & 13,065 & 13,065 & 13,065 \\
\hline $\begin{array}{l}\text { C. IV estimates } \\
\text { Borrowed }\end{array}$ & & & & \\
& -8.6 & -10.8 & -1.25 & 0.223 \\
Observations & $(8.3)$ & $(9.0)$ & $(1.24)$ & $(0.377)$ \\
\hline
\end{tabular}

Notes: For Panel B specification, see Table 3 notes. Panel C displays the second stage of 2SLS estimates using reference-point treatment as an instrument for whether a student borrowed; first stage appears in Panel C of Table 3 Robust standard errors in parentheses; ${ }^{* *} \mathrm{p}<0.01,{ }^{*} \mathrm{p}<0.05,+\mathrm{p}<0.1$. 